\title{
Wound care matrices for chronic leg ulcers: role in therapy
}

This article was published in the following Dove Press journal:

Chronic Wound Care Management and Research

24 July 2015

Number of times this article has been viewed

\author{
Hitomi Sano' \\ Sachio Kouraba ${ }^{2}$ \\ Rei Ogawa' \\ 'Department of Plastic, \\ Reconstructive, and Aesthetic Surgery, \\ Nippon Medical School, Tokyo, Japan; \\ ${ }^{2}$ Sapporo Wound Care and Anti-Aging \\ Laboratory, Sapporo, Japan
}

\begin{abstract}
Chronic leg ulcers are a significant health care concern. Although deep wounds are usually treated by flap transfers, the operation is invasive and associates with serious complications. Skin grafts may be a less invasive means of covering wounds. However, skin grafts cannot survive on deep defects unless high-quality granulation tissue can first be generated in the defects. Technologies that generate high-quality granulation tissue are needed. One possibility is to use wound care matrices, which are bioengineered skin and soft tissue substitutes. Because they all support the healing process by providing a premade extracellular matrix material, these matrices can be termed "extracellular matrix replacement therapies". The matrix promotes wound healing by acting as a scaffold for regeneration, attracting host cytokines to the wound, stimulating wound epithelialization and angiogenesis, and providing the wound bed with bioactive components. This therapy has lasting benefits as it not only helps large skin defects to be closed with thin skin grafts or patch grafts but also restores cosmetic appearance and proper function. In particular, since it acts as a layer that slides over the subcutaneous fascia, it provides skin elasticity, tear resistance, and texture. Several therapies and products employing wound care matrices for wound management have been developed recently. Some of these can be applied in combination with negative pressure wound therapy or beneficial materials that promote wound healing and can be incorporated into the matrix. To date, the clinical studies on these approaches suggest that wound care matrices promote spontaneous wound healing or can be used to facilitate skin grafting, thereby avoiding the need to use invasive surgical tissue transfer strategies.
\end{abstract}

Keywords: biomaterial, chronic wound, leg ulcer, matrix

\section{Introduction}

Chronic leg ulcers are a significant health care concern. Chronic ulcers are wounds that show no tendency to heal after 3 months of appropriate treatment or are not completely healed at 12 months. ${ }^{1}$ It is mainly caused by diabetes, neuropathy, arterial insufficiency, venous insufficiency, and pressure.

Wound healing normally proceeds in four phases, namely, hemostasis, inflammation, proliferation, and remodeling. ${ }^{2}$ Rapid and appropriate wound healing will generally only occur if these four phases and the physiological events that constitute them occur in the appropriate sequence, timing, and duration. Chronic wounds typically do not follow this organized process. ${ }^{3}$

Wound bed preparation is an essential step in wound treatment. It is defined as management of the wound that accelerates endogenous healing or facilitates the effectiveness of other therapeutic measures. ${ }^{4-6}$ The aim of wound bed preparation 
is to convert the molecular and cellular environment of a chronic wound to that of an acute healing wound. ${ }^{46}$ Some of the widely used methods are wound cleansing, debridement, negative pressure wound therapy (NPWT), and application of moist wound dressings. Debridement is particularly important as it serves to remove the necrotic tissue, excessive bacterial burden, and cellular burden of dead and senescent cells, all of which inhibit wound healing. ${ }^{7-14}$ After debridement, pedicled or free-flap transfers are traditionally applied to deep wounds in which bone and/or tendon are/is exposed. However, this operation is invasive and associates with complications, including flap necrosis and infection. These complications are particularly serious problems in elderly people and patients with multiple medical problems and an unfavorable general condition. For these aging or compromised patients, it may be better to use skin grafts, which cover wounds in a less invasive manner. However, skin grafts cannot survive on deep and poorly vascularized defects unless well-vascularized healthy granulation tissue is first generated in the wound. Technologies that promote this are needed. We believe that one possibility is wound care matrices. This section describes how wound care matrices can be used to prepare the wound bed of chronic leg ulcers for subsequent skin grafting.

\section{Wound care matrices}

Wound care matrices are bioengineered skin and soft tissue substitutes. Since they all support the healing process by providing a premade extracellular matrix material, they can be termed "extracellular matrix replacement therapies". The matrix acts as a scaffold for regeneration, stimulates wound epithelialization and angiogenesis, and provides the wound bed with bioactive components, thereby accelerating temporary wound closure. ${ }^{6,15}$ This therapy has lasting benefits as it not only helps large skin defects to be closed with thin skin grafts or patch grafts, it also restores cosmetic appearance and proper function. In particular, since it acts as a layer that slides over the subcutaneous fascia, it provides skin elasticity, tear resistance, and texture. ${ }^{16}$ Numerous therapies and products employing wound care matrices for wound management have been developed recently. The matrices are derived from allogeneic or xenographic tissue, synthetic materials, or a combination of both, and are classified as acellular and cellular materials. ${ }^{17-19}$

One example of a commercially available biosynthetic wound matrix is the collagen-based matrix. It has several advantages as a wound care matrix. First, collagen is the natural substratum for various types of animal cells and is present in tissues in large amounts. ${ }^{20}$ Second, the availability of advanced purification techniques means that biocompatible and biodegenerative collagen matrix can be readily extracted from human and animal tissues. These features make the collagen matrix particularly suitable as a component of the artificial tissue substitutes that are used to reconstruct damaged tissues and organs. ${ }^{21,22}$

Several types of collagen-based artificial skin have been reported since the initial description by Yannas and Burke in 1980. ${ }^{22-25}$ They include Biobrane ${ }^{\circledR}$ (Smith \& Nephew plc, London, UK), Integra ${ }^{\circledR}$ (Siad Healthcare, Milano, Italy), TERUDERMIS (Terumo Corp, Tokyo, Japan), and Pelnac (Smith \& Nephew plc, Tokyo, Japan). When these matrix substitutes are placed onto tissue defects, the collagen acts as a scaffold for regeneration. First, sprouting capillaries and fibroblasts migrate into the collagen, thereby resulting in angiogenesis and fibroplasia. Autogenous regenerating tissue then gradually replaces the atelocollagen. Finally, the poorly vascularized deep defect becomes resurfaced with robust granulation tissue that can be easily covered with a simple skin graft. ${ }^{22-27}$ Collagen matrices have been reported to effectively facilitate the less invasive reconstruction of severe defects with bone and/or tendon exposure that would previously have required invasive tissue transfer. ${ }^{26,27}$ However, it should be noted that they are artificial materials. As such, they may increase the risk of infection and should not be used on clinically diagnosed infected wounds. ${ }^{28}$

Figure 1 illustrates a typical case where a collagen matrix was used to treat a chronic leg ulcer. The patient was a 45-year-old man who suffered from a chronic pyoderma (Figure 1A). The lesion was subjected to surgical debridement followed by application of collagen matrix (Figure 1B and C). Fourteen days later, well-vascularized robust granulation tissue had developed (Figure 1D and E) and a split-thickness skin graft was performed. The patient has remained free of complications in the 3 months since treatment (Figure 1F).

\section{Combination therapies using biomaterials}

Several therapies combine wound care matrices with NPWT or incorporate materials that promote wound healing into the matrix. These include a pharmaceutical agent such as prostaglandin E(1), ${ }^{29}$ growth factors such as basic fibroblast growth factor (bFGF), ${ }^{30-32}$ and cells including bone marrow ${ }^{17,31-37}$ and platelet-rich plasma (PRP). ${ }^{38-42}$ Ono et al showed that collagen matrix combined with prostaglandin $E(1)$ is effective for preventing wound contracture using an in vivo full-thickness skin defect model. ${ }^{29}$ They also showed that collagen matrix 

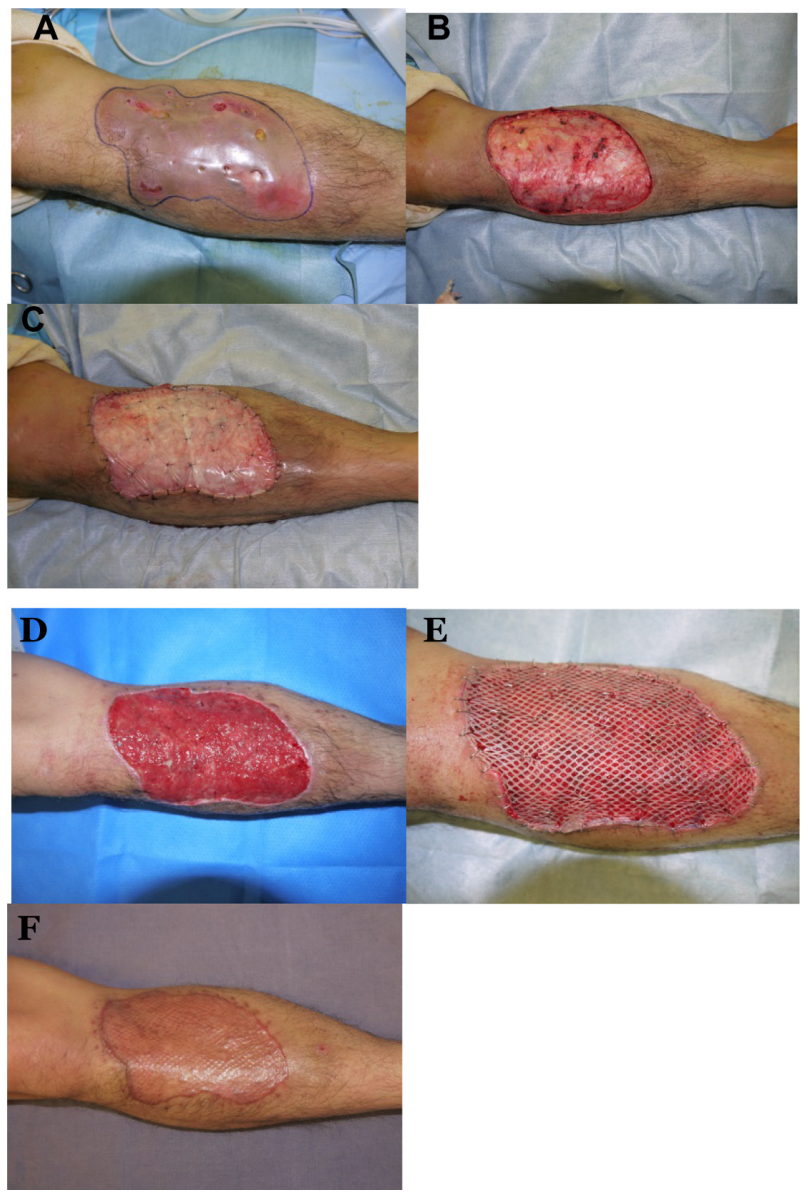

Figure I (A) Nonhealing chronic pyoderma on the right lower limb before wound debridement. (B) After debridement. (C) Application of the collagen matrix after debridement. (D) Robust granulation tissue 2 weeks after collagen matrix application. (E) Split-thickness mesh skin grafting was performed. (F) Healed wound 3 months after grafting.

combined with bFGF, ${ }^{30}$ transforming growth factor beta, ${ }^{31}$ and epidermal growth factor $^{32}$ is effective for preventing wound contracture. This section introduces combination therapies using biomaterials that are already in clinical use.

\section{Combination with bone marrow}

Bone marrow participates in wound healing by providing multipotential progenitor cells that produce growth factors and orchestrate a cascade of events. ${ }^{43}$ Recent evidence suggests that bone marrow may be a source of skin progenitor cells, ${ }^{44,45}$ and several experimental ${ }^{33-36}$ and clinical ${ }^{17,33,37}$ reports show that the topical application of bone marrow cells may promote wound healing. Ichioka et al have developed collagen matrix impregnated with bone marrow. When they applied this material to 53 chronic wounds, successful results were obtained in 44 patients. ${ }^{46-48}$ In addition, Mizuno et al combined mononuclear bone marrow cells and allogeneic cultured dermal substitutes to treat intractable ulcers in patients with critical limb ischemia. They injected the mononuclear cells intramuscularly into the lower leg and around the wound area and applied the allogeneic cultured dermal substitute on the wound surface. All six wounds closed completely and the need for amputation was avoided. ${ }^{49}$

\section{Combination with PRP}

Platelets enhance wound healing by releasing numerous plasma proteins and various growth factors. ${ }^{50-52}$ They stimulate angiogenesis, proliferation and migration, and collagen synthesis. The main growth factors produced by platelets include platelet-derived growth factor, ${ }^{53}$ transforming growth factor beta, ${ }^{54}$ insulin-like growth factor, ${ }^{55}$ endothelial growth factor (EGF), vascular EGF, ${ }^{56}$ and fibroblast growth factor (FGF). ${ }^{57} \mathrm{PRP}$ is defined as plasma that is enriched in platelets. ${ }^{58,59}$ PRP can be generated from autologous blood by a minimally invasive procedure that involves a simple centrifugation step. ${ }^{59-63}$ Several studies show that PRP has beneficial effects in wound treatment. ${ }^{38-42}$ For example, Knighton et al observed that when chronic lower extremity ulcers were treated with platelet-derived wound-healing formula (platelet releasate that is suspended in a collagen base), all exhibited enhanced reepithelialization. ${ }^{40}$ Similarly, Minamimura et al found that when 16 chronic limb ulcers were treated with collagen matrix impregnated with PRP, 13 healed successfully. ${ }^{41,42}$

\section{Combination with growth factors}

Wound healing may be promoted by the topical application of cytokines such as platelet-derived growth factor, EGF, and bFGF. Of these, bFGF is commercially available. In 1974, Gospodarowicz first isolated FGF from bovine pituitary glands and found that this protein accelerated the proliferation of fibroblasts. ${ }^{64-66} \mathrm{FGF}$ not only stimulates the fibroblast proliferation ${ }^{67}$ but also promotes the proliferation of endothelial cells and keratinocytes and the mitogenesis of mesenchymal cells; consequently, FGF induces angiogenesis, granulation tissue formation, and epithelialization. ${ }^{64,67,68}$ Several clinical studies have found that bFGF is safe and effective for the treatment of various wounds, including diabetic ulcers, pressure ulcers, and burns. ${ }^{69,70}$ Several experimental studies also showed that bFGF is beneficial for ulcers when it is combined with matrix. ${ }^{71-74}$ For example, when the novel artificial dermis consisting of a collagen/gelatin sponge that is capable of sustained bFGF release, developed by Morimoto et al., was used to treat 17 chronic leg ulcers, the wound bed improved in 16 patients. ${ }^{73,74}$ Several recent basic research 
studies also suggest that bFGF-matrix combinations may promote wound healing. ${ }^{71,72}$

\section{Combination with NPWT}

NPWT is a treatment modality that has become widely adopted for a broad range of wound indications since its advent over 15 years ago. The system consists of an electronically controlled pump and foam dressing that drains the wound. An adjustable negative pressure is applied via an airtight adhesive film that covers the wound. NPWT improves wound healing by creating a moist wound-healing environment, reducing tissue edema, removing bacterial products, promoting blood circulation, contracting the wound edges, mechanically stimulating the wound bed, and influencing blood perfusion at the wound edge. All these effects may promote angiogenesis and the formation of granulation tissue. ${ }^{75-77}$ There are two ways to use NPWT with wound care matrices: NPWT is used for 1) wound bed preparation before the use of wound care matrices and 2) fixation of wound care matrices. Menn et al used artificial dermis with NPWT for lower extremity reconstruction and concluded that a dermal substitute and NPWT with delayed skin graft application can provide a reasonable tissueengineered alternative to free-tissue transfer in medically compromised patients. ${ }^{78}$

\section{Conclusion}

Wound care matrices can be used to successfully close wounds either by promoting spontaneous healing or by preparing the wound bed for skin grafting, which is a less invasive procedure than surgical tissue transfer. However, we should always bear in mind that topical wound therapeutic management strategies only work effectively on adequately perfused wound beds that have a moist environment without devitalized tissue or a critical bacterial burden.

\section{Acknowledgment}

No financial support was provided for this study.

\section{Disclosure}

The authors report no conflicts of interest in this work.

\section{References}

1. Kahle B, Hermanns HJ, Gallenkemper G. Evidence-based treatment of chronic leg ulcers. Dtsch Arztebl Int. 2011;108(14):231-237.

2. Hodde JP, Johnson CE. Extracellular matrix as a strategy for treating chronic wounds. Am J Clin Dermatol. 2007;8(2):61-66.

3. Lazarus GS, Cooper DM, Knighton DR, et al. Definitions and guidelines for assessment of wounds and evaluation of healing. Arch Dermatol. 1994;130(4):489-493.
4. Schultz GS, Sibbald RG, Falanga V, et al. Wound bed preparation: a systematic approach to wound management. Wound Repair Regen. 2003;11:1s-23s.

5. Sibbald RG, Williamson D, Orsted HL. Preparing the wound bed: debridement, bacterial balance, and moisture balance. Ostomy Wound Manage. 2000;46:14-35.

6. Hopf HW, Ueno C, Aslam R, et al. Guidelines for the treatment of arterial insufficiency ulcers. Wound Repair Regen. 2006;14(6):693-710.

7. Steed DL. Debridement. Am J Surg. 2004;187(Suppl 5A):71s-74s.

8. Sieggreen MY, Maklebust J. Debridement: choices and challenges. Adv Wound Care. 1997;10:32-37.

9. Bradley M, Cullum N, Sheldon T. The debridement of chronic wounds: a systematic review. Health Technol Assess. 1999;3(17 pt 1):1-78.

10. Mosher BA, Cuddigan J, Thomas DR, et al. Outcomes of 4 methods of debridement using a decision analysis methodology. Adv Wound Care. 1999;12:81-88.

11. Davies CE, Turton G, Woolfrey G, Elley R, Taylor M. Exploring debridement options for chronic venous leg ulcers. Br J Nurs. 2005;14: 393-397.

12. Steed DL, Donohoe D, Webster MW, Lindsley L. Effect of extensive debridement on the healing of diabetic foot ulcers. Diabetic Ulcer Study Group. J Am Coll Surg. 1996;183:61-64.

13. Ayello EA, Cuddigan J. Debridement: controlling the necrotic/cellular burden. Adv Skin Wound Care. 2004;17:66-75.

14. Schmeller W, Gaber Y, Gehl HB. Shave therapy is a simple, effective treatment of persistent venous leg ulcers. J Am Acad Dermatol. 1998;39:232-238.

15. Bouza C, Munoz A, Amate JM. Efficacy of modern dressings in the treatment of leg ulcers: a systematic review. Wound Repair Regen. 2005; 13:218-229.

16. Sheridan RL, Hegarty M, Tompkins RG, Burke JF. Artificial skin in massive burns - results to ten years. Eur J Plastic Surg. 1994;17:91-93.

17. Metcalfe AD, Ferguson MW. Tissue engineering of replacement skin: the crossroads of biomaterials, wound healing, embryonic development, stem cells and regeneration. $J R$ Soc Interface. 2007;4(14): 413-437.

18. Bello YM, Falabella AF, Eaglstein WH. Tissue-engineered skin. Current status in wound healing. Am J Clin Dermatol. 2001;2(5):305-313.

19. Papanas N, Eleftheriadou I, Tentolouris N, Maltezos E. Advances in the topical treatment of diabetic foot ulcers. Curr Diabetes Rev. 2012; 8(3):209-218.

20. Linsenmayer TF. Collagen. In: Hay ED, editor. Cell Biology of Extracellular Matrix. New York: Plenum Press; 1985:5-37.

21. Chvapil M, Kronenthal RL, Winkle WV Jr. Medical and surgical applications of collagen. In: Hall DA, Jackson DS, editors. International Review of Connective Tissue Research. Vol 6. New York: Academic Press; 1973:1-61. [ISBN 9780123637109].

22. Doillon CJ, Silver FH. Collagen-based wound dressing: effects of hyaluronic acid and fibronectin on wound healing. Biomaterials. 1986;7:3-8.

23. Yannas IV, Burke JF. Design of an artificial skin I. Basic design principles. J Biomed Mater Res. 1980;14:65-81.

24. Leipziger LS, Glushko V, DiBernardo B, et al. Dermal wound repair: role of collagen matrix implants and synthetic polymer dressing. J Am Acad Dermatol. 1985;12:409-419.

25. Bell E, Ehrlich HP, Buttle DJ, Nakatsuji T. A living tissue formed in vitro and accepted as a full thickness skin equivalent. Science. 1981;211: 1042-1054.

26. Braden BJ, Bergstrom N. Clinical utility of the Braden scale for predicting pressure sore risk. Decubitus. 1989;2(44-46):50-51.

27. Dantzer E, Braye FM. Reconstructive surgery using an artificial dermis (Integra): results with 39 grafts. Br J Plast Surg. 2001;54: 659-664.

28. Hill JL, Wong L, Kemper P, Buseman J, Davenport DL, Vasconez HC. Infectious complications associated with the use of acellular dermal matrix in implant-based bilateral breast reconstruction. Ann Plast Surg. 2012;68(5):432-434. 
29. Ono I, Zhou LJ, Tateshita T. Effects of a collagen matrix containing prostaglandin E(1) on wound contraction. J Dermatol Sci. 1999;48(5): 106-115.

30. Ono I, Tateshita T, Inoue M. Effects of a collagen matrix containing basic fibroblast growth factor on wound contraction. J Biomed Mater Res. 1998;6(3):621-630.

31. Tateshita T, Ono I, Kaneko F. Effects of collagen matrix containing transforming growth factor (TGF)-beta(1) on wound contraction. J Dermatol Sci. 2001;25(2):104-113.

32. Inoue M, Ono I, Tateshita T, Kuroyanagi Y, Shioya N. Effect of a collagen matrix containing epidermal growth factor on wound contraction. Wound Repair Regen. 1998;6(3):213-222.

33. Badiavas EV, Falanga V. Treatment of chronic wounds with bone marrow-derived cells. Arch Dermatol. 2003;139:510-516.

34. Sivan-Loukianova E, Awad OA, Stepanovic V, Bickenbach J, Schatteman GC.CD34_blood cells accelerate vascularization and healing of diabetic mouse skin wounds. J Vasc Res. 2003;40:368-377.

35. McFarlin K, Gao X, Liu YB, et al. Bone marrow derived mesenchymal stromal cells accelerate wound healing in the rat. Wound Repair Regen. 2006;14:471-478.

36. Borue X, Lee S, Grove J, et al. Bone marrow-derived cells contribute to epithelial engraftment during wound healing. Am J Pathol. 2004;165:1767-1772.

37. Ramsey SD, Newton K, Blough D, et al. Incidence, outcomes, and cost of foot ulcers in patients with diabetes. Diabetes Care. 1999;22 382-387.

38. Driver VR, Hanft J, Fylling CP, Beriou JM; Autologel Diabetic Foot Ulcer Study Group. A prospective, randomized, controlled trial of autologous platelet-rich plasma gel for the treatment of diabetic foot ulcers. Ostomy Wound Manage. 2006;52(6):68-70, 72, 74 assim.

39. Giano C, Tenewitz FE, Wilson RC, Moyles BG. The treatment of chronic nonhealing wounds using autologous platelet-derived growth factors. J. Foot Ankle Surg. 1993;32:263-268.

40. Knighton DR, Ciresi K, Fiegel VD, Schumerth S, Butler E, Cerra F. Stimulation of repair in chronic, nonhealing, cutaneous ulcers using platelet-derived wound healing formula. Surg Gynecol Obstet. 1990;170: 56-60.

41. Minamimura A, Ichioka S, Sano H, Sekiya N. Comparison of collagen matrix treatment impregnated with platelet rich plasma vs bone marrow. J Plast Surg Hand Surg. 2014;48(1):15-20.

42. Minamimura A, Ichioka S, Sano H, Shoichi Ishikawa S. Treatment of non-healing limb ulcers with platelet-rich plasma. JPRAS. 2013;33(5): 304-309.

43. Gillitzer R, Goebeler M. Chemokines in cutaneous wound healing. J Leukoc Biol. 2001;69:513-521.

44. Krause DS, Theise ND, Collector MI, et al. Multi-organ, multilineage engraftment by a single bone marrow-derived stem cell. Cell. 2001;105:369-377.

45. Liang L, Bickenbach JR. Somatic epidermal stem cells can produce multiple cell lineages during development. Stem Cells. 2002;20: 21-31.

46. Ichioka S, Kouraba S, Sekiya N, Ohura N, Nakatsuka T. Bone marrowimpregnated collagen matrix for wound healing: experimental evaluation in a microcirculatory model of angiogenesis, and clinical experience. Br J Plast Surg. 2005;58(8):1124-1130.

47. Ichioka S, Yokogawa H, Sekiya N, et al. Determinants of wound healing in bone marrow-impregnated collagen matrix treatment: impact of microcirculatory response to surgical debridement. T Wound Repair Regen. 2009;17(4):492-497.

48. Sano H, Ichioka S, Kouraba S, et al. Treatment of venous ulcers with bone marrow-impregnated collagen matrix. J Plast Surg Hand Surg. 2012;46(1):37-44.

49. Mizuno H, Miyamoto M, Shimamoto M, Koike S, Hyakusoku H, Kuroyanagi Y. Therapeutic angiogenesis by autologous bone marrow cell implantation together with allogeneic cultured dermal substitute for intractable ulcers in critical limb ischaemia. J Plast Reconstr Aesthet Surg. 2010;63(11):1875-1882.
50. Everts PA, Brown Mahoney C, Hoffmann JJ, et al. Platelet-rich plasma preparation using three devices: implications for platelet activation and platelet growth factor release. Growth Factors. 2006;24(3):165-171.

51. Knighton DR, Ciresi KF, Fiegel VD, Austin LL, Butler EL. Classification and treatment of chronic nonhealing wounds. Successful treatment with autologous platelet-derived wound healing factors (PDWHF). Ann Surg. 1986;204(3):322-330.

52. Knighton DR, Doucette M, Fiegel VD, Ciresi K, Butler E, Austin L. The use of platelet derived wound healing formula in human clinical trials. Prog Clin Biol Res. 1988;266:319-329.

53. Bennett SP, Griffiths GD, Schor AM, Leese GP, Schor SL. Growth factors in the treatment of diabetic foot ulcers. Br J Surg. 2003;90:133-146.

54. Assoian RK, Sporn MB. Type beta transforming growth factor in human platelets: release during platelet degranulation and action on vascular smooth muscle cells. J Cell Biol. 1986;102:1217-1223.

55. Hock JM, Gentrella M, Canalis E. Insulin-like growth factor I has independent effects on bone matrix formation and cell replication. Endocrinology. 1988;122:254-260.

56. Möhle R, Green D, Moore MA, Nachman RL, Rafii S. Constitutive production and thrombin-induced release of vascular endothelial growth factor by human megakaryocytes and platelets. Proc Natl Acad Sci US A. 1997;94:663-668.

57. Brunner G, Nguyen H, Gabrilove J, Rifkin DB, Wilson EL. Basic fibroblast growth factor expression in human bone marrow and peripheral blood cells. Blood. 1993;81:631-638.

58. Mehta S, Watson JT. Platelet rich concentrate: basic science and current clinical applications. J Orthop Trauma. 2008;22(6):432-438.

59. Marx RE. Platelet-rich plasma (PRP): what is PRP and what is not PRP? Implant Dent. 2001;10(4):225-228.

60. Shashikiran ND, Reddy VV, Yavagal CM, Zakirulla M. Applications of platelet-rich plasma (PRP) in contemporary pediatric dentistry. J Clin Pediatr Dent. 2006;30(4):283-286.

61. Bhanot S, Alex JC. Current applications of platelet gels in facial plastic surgery. Facial Plast Surg. 2002;18(1):27-33.

62. Roberts AB, Sporn MB. Physiological actions and clinical applications of transforming growth factor-beta (TGFbeta). Growth Factors. 1993;8:1-9.

63. Marx RE, Carlson ER, Eichstaedt RM, Schimmele SR, Strauss JE, Georgeff KR. Platelet-rich plasma: growth factor enhancement for bone grafts. Oral Surg Oral Med Oral Pathol Oral Radiol Endod. 1998;85:638-646.

64. Gospodarowicz D. Molecular and developmental biology aspects of fibroblast growth factor. Adv Exp Med Biol. 1988;234:23-39.

65. Gospodarowicz D, Ferrara N, Schweigerer L, Neufeld G. Structural characterization and biological functions of fibroblast growth factor. Endocr Rev. 1987;8:95-114.

66. Greenhalgh DG, Sprugel KH, Murray MJ, Ross R. PDGF and FGF stimulate wound healing in the genetically diabetic mouse. Am J Pathol. 1990;136:1235-1246.

67. Floss T, Arnold HH, Braun T. A role for FGF-6 in skeletal muscle regeneration. Genes Dev. 1997;11:2040-2045.

68. Menetrey J, Kasemkijwattana C, Day CS, et al. Growth factors improve muscle healing in vivo. J Bone Joint Surg Br. 2000;82:131-137.

69. Ishibashi Y, Harada S, Takemura T, et al. Clinical effectiveness of KCB1(bFGF) on patients with skin ulcerations clinical trial for 12 weeks. J Clin Therapeut Med. 1996;12:2117-2129.

70. Ichioka S, Ohura N, Nakatsuka T. The positive experience using a growth factor product on deep wounds with bone exposure. J Wound Care. 2005;14(3):105-109.

71. Wu Z, Fan L, Xu B, Lin Y, Zhang P, Wei X. Use of decellularized scaffolds combined with hyaluronic acid and basic fibroblast growth factor for skin tissue engineering. Tissue Eng Part A. 2015;21(1-2):390-402.

72. Li W, Lan Y, Guo R, Zhang Y, Xue W, Zhang Y. In vitro and in vivo evaluation of a novel collagen/cellulose nanocrystals scaffold for achieving the sustained release of basic fibroblast growth factor. J Biomater Appl. 2015;29(6):882-893. 
73. Morimoto N, Yoshimura K, Niimi M, et al. Novel collagen/gelatin scaffold with sustained release of basic fibroblast growth factor: clinical trial for chronic skin ulcers. Tissue Eng Part A. 2013;19(17-18):1931-1940.

74. Takemoto S, Kawai K, Yokode M, Shimizu A, Suzuki S. An exploratory clinical trial for combination wound therapy with a novel medical matrix and fibroblast growth factor in patients with chronic skin ulcers: a study protocol. Am J Transl Res. 2012;4(1):52-59.

75. Huang C, Leavitt T, Bayer LR, Orgill DP. Effect of negative pressure wound therapy on wound healing. Curr Probl Surg. 2014;51(7): 301-331.
76. Peinemann F, Sauerland S. Negative-pressure wound therapy: systematic review of randomized controlled trials. Dtsch Arztebl Int. 2011;108(22):381-389.

77. Borgquist $\mathrm{O}$, Ingemansson R. Malmsjö M. Individualizing the use of negative pressure wound therapy for optimal wound healing: a focused review of the literature. Ostomy Wound Manage. 2011;57(4):44-54.

78. Menn ZK, Lee E, Klebuc MJ. Acellular dermal matrix and negative pressure wound therapy: a tissue-engineered alternative to free tissue transfer in the compromised host. J Reconstr Microsurg. 2012;28(2):139-144.

\section{Publish your work in this journal}

Chronic Wound Care Management and Research is an international, peer reviewed, open access, online journal publishing original research, reviews, editorials, and commentaries on the causes and management of chronic wounds and the major issues related to chronic wound management. Topics also include chronic wounds as comorbidities to other conditions, patient adherence to therapy, and the economic burden of chronic wounds. The manuscript management system is completely online and includes a very quick and fair peer review system, which is all easy to use. Visit http://www.dovepress.com/testimonials.php to read real quotes from published authors.

Submit your manuscript here: http://www.dovepress.com/chronic-wound-care-management-and-research-journal 